\title{
Use of unmanned aerial vehicle to calculate soil loss ${ }^{1}$
}

\author{
Ana Karolyna Nunes Amaral ${ }^{2}$, Chrystiano Alves de Souza², \\ Renata Santos Momoli $^{2}$, Luis Felipe Soares Cherem ${ }^{2}$
}

\section{ABSTRACT}

Satellite remote sensing systems are widely used in environmental studies for providing regional scale analyses with high temporal resolution. On the other hand, when local small scale spatial studies based on very high resolution data at specific moments are involved, unmanned aerial vehicles have been alternatively adopted. The present case study aimed to carry out the morphometric analysis and quantify the soil loss in two sinkholes located in Oxisol on carbonate rocks of the Paranoá Group, in an agricultural area of Niquelândia, Goiás state, Brazil, using unmanned aerial vehicle, in two periods. From the analyzed satellite images, it was estimated that the emergence period of the sinkholes was between December 2018 and April 2019. Based on the aerial survey carried out, $35.53 \mathrm{~m}^{2}$ of eroded area and 236.89 metric tons of soil loss were observed for the sinkhole 1, as well $299.96 \mathrm{~m}^{2}$ of area and 663.47 metric tons of loss in the first period and $961.66 \mathrm{~m}^{2}$ of area and 4,241.68 metric tons of loss after six months for the sinkhole 2.

KEYWORDS: Aerophotogrammetry, karst, soil conservation.

\section{INTRODUCTION}

The use of remote sensing has increased significantly and is widely employed in environmental studies. This allows temporal analysis and visualization of large land areas within a brief timeframe, shortening field studies, which can be quite costly for researchers (Souza Filho et al. 2006, Silva 2014).

Satellite imaging and remote sensing systems, being the most well-known the CBERS, LANDSAT and SENTINEL satellite programs and their products, are increasingly available to the global community free of charge, enabling different types of analyses on a small and medium cartographic scale (Pereira

\section{RESUMO}

\section{Utilização de aeronave remotamente} pilotada no cálculo de perda de solo

O sensoriamento remoto por sistemas orbitais é bastante utilizado em estudos ambientais, por permitir análises em escala regional com alta resolução temporal. Já para estudos locais, em pequena escala espacial, com base de dados em altíssima resolução e em momentos específicos, aeronaves pilotadas remotamente têm sido adotadas alternativamente. Este estudo de caso objetivou efetuar a análise morfométrica e quantificação da perda de solo em duas dolinas localizadas em Latossolo sobre rochas carbonáticas do Grupo Paranoá, em área agrícola de Niquelândia (Goiás), utilizando-se aeronave pilotada remotamente, em dois períodos. A partir das imagens de satélites analisadas, estimou-se que o período de surgimento das dolinas foi entre dezembro de 2018 a abril de 2019. Com base no levantamento aéreo realizado, foram observados $35,53 \mathrm{~m}^{2}$ de área erodida e $236,89 \mathrm{t}$ de perda de solo para a dolina 1 , bem como $299,96 \mathrm{~m}^{2}$ de área e $663,47 \mathrm{t}$ de perda no primeiro período e $961,66 \mathrm{~m}^{2}$ de área e 4.241,68 t de perda após seis meses para a dolina 2 .

PALAVRAS-CHAVE: Aerofotogrametria, carste, conservação de solos.

et al. 2017). However, when a more detailed analysis is required, these products may not sufficiently represent the reality of the area for reasons of scale and accuracy. For high spatial resolution and cartographic precision, costly commercial satellite images are available (Adão et al. 2017).

In order to overcome the problems and limitations of remote sensing and obtain data at any moment, aerophotogrammetry methods were developed using unmanned aerial vehicles (UAVs), also known as drones. These systems can provide images with centimeter resolution, thereby generating products on large cartographic scales, depending on the equipment used, and providing information with high spatial resolution and cartographic precision

${ }^{1}$ Received: Aug. 12, 2021. Accepted: Oct. 14, 2021. Published: Nov. 26, 2021. DOI: 10.1590/1983-40632021v5169942.

${ }^{2}$ Universidade Federal de Goiás, Instituto de Estudos Socioambientais, Laboratório de Geomorfologia, Pedologia e Geografia

Física, Goiânia, GO, Brasil. E-mail/ORCID: ana.nunes.ufg@gmail.com/0000-0002-9406-7067; chfetgeo@gmail.com/ 0000-0001-7935-6306; rsmomoli@ufg.br/0000-0001-7309-4974; luischerem@ufg.br/0000-0002-4119-6690. 
(Pessi et al. 2020). They also can be used to survey, identify and monitor the features and structures of karst environments, thereby reducing risks for researchers during conventional surveys (Cunha et al. 2020).

Sinkholes are a major feature among the different geoforms produced in this type of environment and consist of elliptical depressions that occur on the surface of karst landscapes (Ford \& Williams 2007). These depressions are formed by the intense dissolution and collapse of portions of the relief, especially soluble rocks such as evaporites and carbonates (Pardo-Igúzquiza et al. 2013, Carvalho et al. 2014).

Sinkholes are important in the environmental analysis of landscape vulnerability, given that these depressions exhibit high geological risk due to their low stability and connections between the surface and the subterranean karst system via flow paths, where percolation occurs more easily than in a rocky medium (Zwahlen 2004). The fragilities of karsts, combined with soil use, may heighten environmental and human health risks due to sudden collapses (Vestena et al. 2002). The erosion of cultivated soils, for example, may transport sediments and pollutants (pesticides, herbicides and others) into these cavities, causing sedimentation and contaminating underground water resources over a wide area downstream from the impact, which may compromise the supply to humans and the aquatic life that inhabits this environment (Urich 2002, Hiruma et al. 2007).

According to Ferreira \& Uagoda (2020), sinkhole studies in Brazil are concentrated primarily in the southeastern states of Minas Gerais and São Paulo, with few in the Midwest region. Another gap is the lack of research on the occurrence and evolution of sinkholes in cultivated areas subjected to intensive mechanized agriculture.

Research on expanding karst agricultural landscapes, where natural fragilities may compromise agricultural work safety and environmental quality, is therefore paramount (Williams 1993, Teles \& Morais 2019). As such, the present study aimed at calculating the soil loss in karst depressions (sinkholes) in land cultivated with soybean and maize, developed on metasedimentary rocks of the Paranoá Group, as well as to characterize and identify the evolution of sinkholes using a set of products obtained from high-resolution UAV images.

\section{MATERIAL AND METHODS}

The study area is located in the Legado Verdes do Cerrado reserve, in Niquelândia, northern Goiás state, Brazil. The reserve covers approximately 27,000 ha, dedicated primarily to conserving an area of Cerrado (Brazilian Savanna) biome of around 3,000 ha used to grow soybean and maize. Two sinkholes were identified in the cultivated area, denominated sinkhole 1, located between the UTM coordinates N8386528 and E775027 m, and sinkhole 2, between N8385957 and E771583 m (Figure 1).

Sedimentary and metamorphic rocks from the Paranoá Group predominate in the region, including carbonate rocks such as limestone and dolomite, responsible for the presence of sinkholes and caves (Lacerda Filho et al. 1999). The altitude ranges from $556 \mathrm{~m}$ in the flatter areas to $1,252 \mathrm{~m}$ in the steeper ones. The gradient at the center of the watershed is classified as slightly undulating, between 3 and $8 \%$, but areas near the drainage headlands are classified as mountainous, with a slope of more than $45 \%$ (Lepsch et al. 1983). The predominant soil in the region is Yellow-Red Latosol (Santos et al. 2011) or Oxisol (USDA 2014).

The climate of the region is classified as tropical Aw, according to Köppen, with a rainy season from November to March and a dry season from April to October. The average annual rainfall ranges from 1,200 to $1,400 \mathrm{~mm}$ and the average annual temperature is $23{ }^{\circ} \mathrm{C}$, with minimum of $18^{\circ} \mathrm{C}$ and maximum of $31^{\circ} \mathrm{C}$ (Nascimento \& Novais 2020). The climate conditions favor the formation of karst landforms, due to the increase in vegetation and biochemical activity, which causes a greater acidification, promoting the formation of vertical flows by dissolution (Carvalho et al. 2014).

An unmanned aerial vehicle (UAV) was used to conduct aerophotogrammetric field surveys of the two sinkholes studied, in two periods, one in the rainy (November 2020) and the other in the dry season (May 2021). The UAV was a DJI PHANTOM 4 PRO multimotored drone, used at an average height of $120 \mathrm{~m}$ above the ground, configured in P-mode, at constant speed of approximately $6 \mathrm{~m} \mathrm{~s}^{-1}$, with $85 \%$ of frontal and $80 \%$ of lateral overlap, obtaining images with spatial resolution between 1.5 and $3.5 \mathrm{~cm}$.

It is important to point out that no ground control points were used in these surveys, due to the lack of a geodetic GPS receiver. However, according 


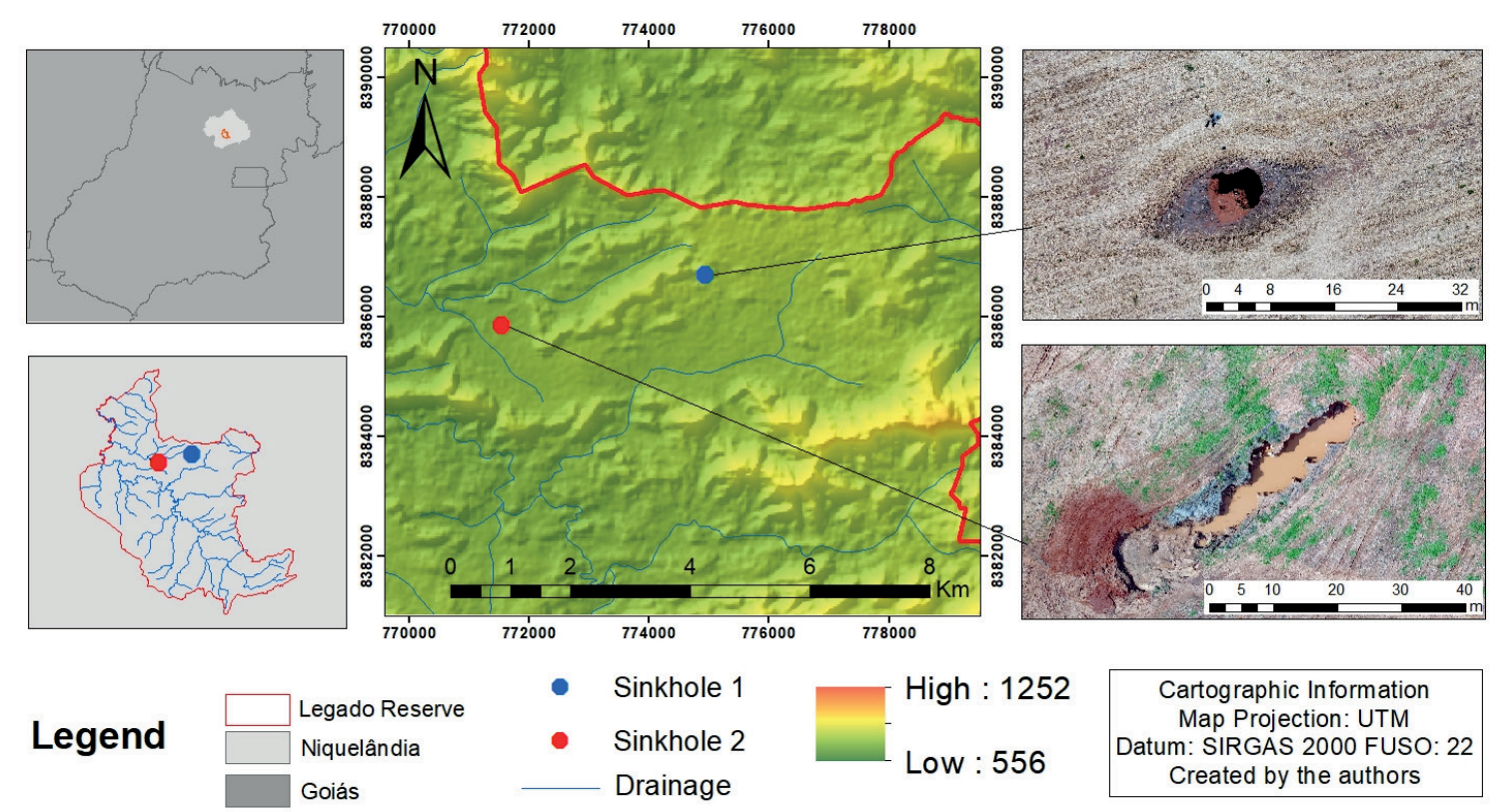

Figure 1. Study area, located in the Legado Verdes do Cerrado reserve (Niquelândia, Goiás state, Brazil).

to Barcelos (2017), the lack of ground control points does not significantly change the quality and characterization of small areas. The absolute positioning method selected is widely applied for quick surveys and uses the GPS receiver built into the equipment (Zanetii 2017).

The accuracy of the survey depends on the equipment and, in the case of the PHANTOM 4 PRO, vertical accuracy varies between $\pm 0.1 \mathrm{~m}$ (with visual positioning) and $\pm 0.5 \mathrm{~m}$ (with GPS positioning) and horizontal between $\pm 0.3 \mathrm{~m}$ (with visual positioning) and $\pm 1.5 \mathrm{~m}$ (with GPS positioning). The images were processed in the Pix4Dmapper software, which processes images of small areas using calculations of sophisticated algorithms and point cloud densification (Boonpook et al. 2018), and generated a set of products such as orthomosaic, digital terrain and elevation models (DTM and DEM, respectively), and pixel clouds, among others. The ArcGis 10.3 software was also used to calculate the morphometric variables of the sinkholes identified in the study area, where the axes, perimeter, area and volume were surveyed.

The volume was determined using the surface volume tool, which calculates the difference between the reference surface (represented by the surface of the terrain directly surrounding the sinkholes) and the surface relative to the bottom of the sinkholes obtained by the DEM. In order to determine the amount of soil lost to the subjacent karst cavities, the soil density was multiplied by the measured volume to calculate the loss in metric tons: Ms $=$ Ds $x \mathrm{~V}$, where: Ms is the soil mass ( $g$ and metric tons), Ds the soil density $\left(\mathrm{g} \mathrm{cm}^{-3}\right)$ and $\mathrm{V}$ the volume $\left(\mathrm{cm}^{3}\right.$ and $\left.\mathrm{m}^{3}\right)$

The average soil density (Ds) of the Oxisol cultivated in the studied region was $1.4 \mathrm{~g} \mathrm{~cm}^{-3}$, determined from non-deformed samples, using metallic volumetric rings (Teixeira et al 2017), at a depth up to $0.6 \mathrm{~m}$.

\section{RESULTS AND DISCUSSION}

The UAV image processing and field visits made it possible to conduct the morphometric characterization of the karst features identified. Sinkhole 1 covers an area of $35,53 \mathrm{~m}^{2}$, with an irregular border, diameters varying between 5 and $6 \mathrm{~m}$ and maximum depth of $9 \mathrm{~m}$ (Figure 2). This sinkhole is located in a soybean plantation, where evidence of recent agricultural machinery activity was observed near its borders.

Based on bibliography regarding the morphogenesis of karst features (Ford \& Williams 2007), this depression was characterized as a collapse sinkhole, due to the vertical migration caused by abrupt ground settlement. Given that this occurred on a pedological layer, it was classified as a covercollapse sinkhole. 


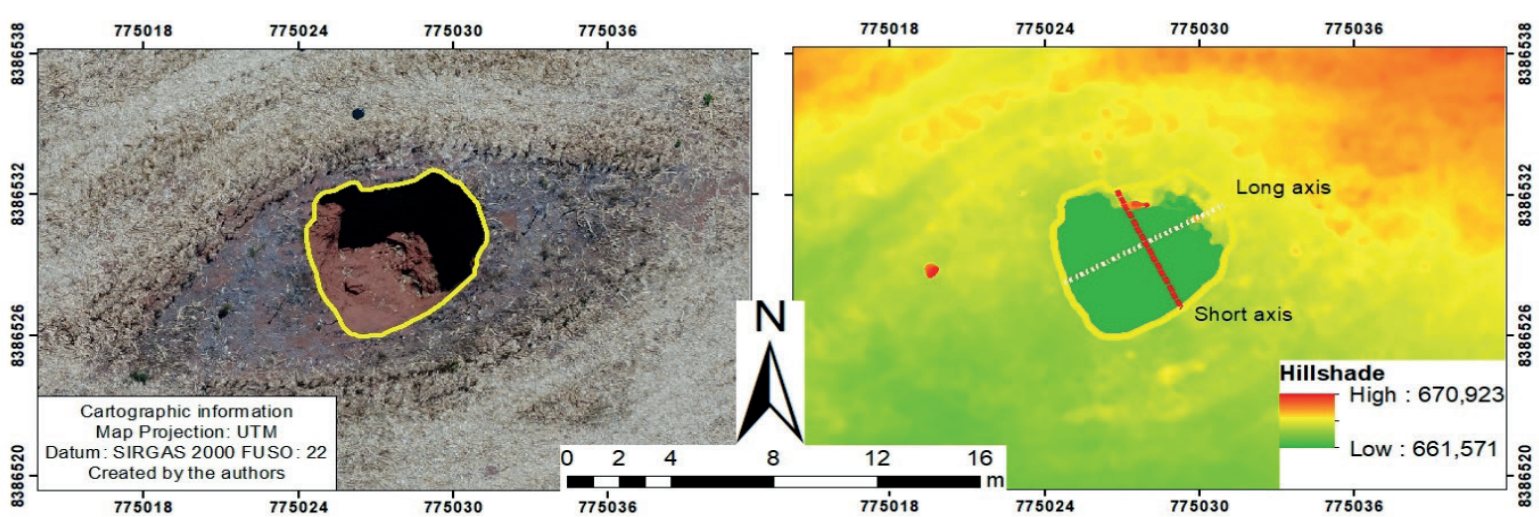

Figure 2. Sinkhole 1: survey carried out in November 2020 (Niquelândia, Goiás state, Brazil).

Surface collapse occurs as a consequence of the loss of base support, and when the weight of materials suspended over the cavity exceeds its mechanical strength (support), this space increases slowly and gradually, due to dissolution of the carbonate substrate on the pedological cover suspended by structural control. Later, the overlying detritic materials tend to move gravitationally through these preferential flow pathways (Beck 2012).

In the second survey of the sinkhole 1, conducted in May 2021, the feature could no longer be seen, because it had been covered by machines and mechanical implements, with the soil removed from the neighboring area and completely filling the sinkhole cavity (Figure 3).

This measure, used to mitigate the impact and allow the area to be cultivated, may not be ideal, since karst systems are connected to the subterranean environment, and these materials can be transported to aquifers via conduits, causing groundwater contamination by agricultural inputs and underground sedimentation. In addition, the material used to cover the depression, removed from the adjacent surface, may characterize additional impacts, such as loss of the most fertile and productive soil layer. Morphometric calculations were made to characterize this feature (Table 1).

Unlike the sinkhole 1 , the sinkhole 2 is more elongated, and $46.62 \mathrm{~m}$ long on its main axis. The area calculated for the depression was $299.96 \mathrm{~m}^{2}$, with a maximum depth of $3.93 \mathrm{~m}$ (Figure 4).

Several factors may influence the creation of DEM and calculation of morphometric variables. Given that the drone calculates altitude based on the observed surface, the measured depth was influenced by the presence of water at the bottom of the sinkhole resulting from the constant rainfall in the period. Thus, the real depth of the depression is greater than the measured value. However, in order to not overestimate the result, analyses were conducted with the calculated value.

Carbonate rocks were observed during the field visits and exposed as the sinkhole increased in

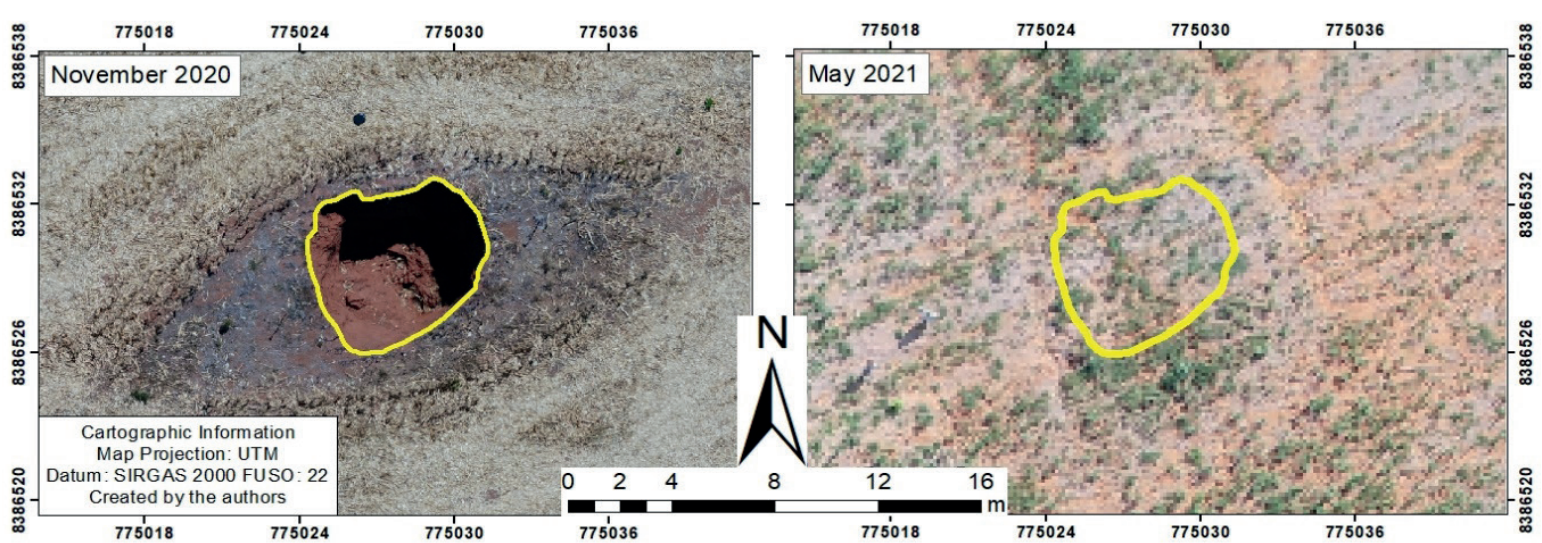

Figure 3. Sinkhole 1: comparison between surveys carried out in November 2020 and May 2021 (Niquelândia, Goiás state, Brazil). 
Table 1. Morphometric characterization of the sinkhole 1 (Niquelândia, Goiás state, Brazil).

\begin{tabular}{lcccc}
\hline \multicolumn{1}{c}{ Period } & Area $\left(\mathrm{m}^{2}\right)$ & Maximum depth $(\mathrm{m})$ & Long axis & Short axis \\
\hline November 2020 & 35.53 & 9.12 & 6.99 & 5.60 \\
May 2021* & - & - & - & - \\
\hline * The sinkhole did not show morphometric values in this month, as it had been grounded. & &
\end{tabular}

* The sinkhole did not show morphometric values in this month, as it had been grounded.

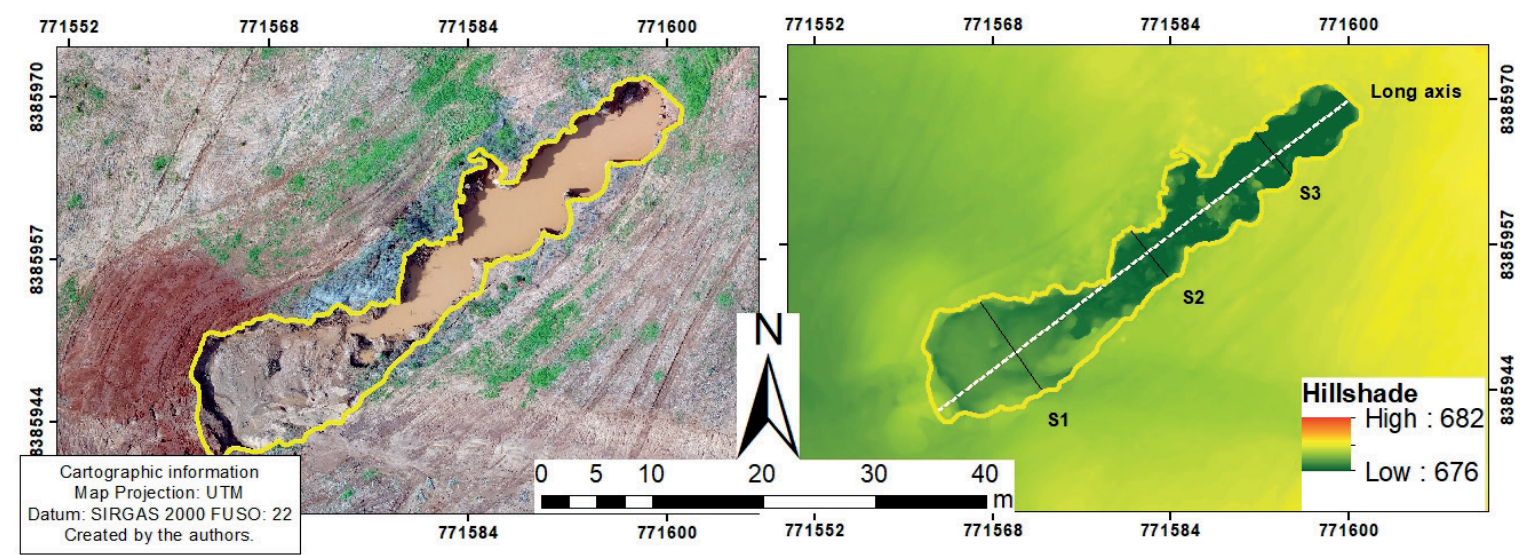

Figure 4. Sinkhole 2: survey carried out in November 2020 (Niquelândia, Goiás state, Brazil).

size. The presence of sectioned planting rows shows that the area has been used for agriculture and that machines operated near the sinkhole.

In the second aerial survey performed in the area, no water was observed at the bottom of the sinkhole, because the flight occurred during the dry season, allowing the real depth to be measured. Substantial changes were observed in the area and shape of the sinkhole from one period to the other (Figure 5). Based on the morphometric calculations of the sinkhole in the periods analyzed, it was found that the area more than doubled in 6 months, with approximately $962 \mathrm{~m}^{2}$ and maximum depth of $6.95 \mathrm{~m}$ (Table 2).
In order to identify the sinkhole emergence period, satellite images from 2016 were analyzed, coinciding with the onset of plant cover conversion and soil use in the area (Figure 6).

According to Mapbiomas (2021) data, there was a substantial increase in soybean and maize crops toward the northeast of the study area. The classes "Savanna Formation", "Field Formation" and "Planted Forest" were the most compromised by these changes, losing around $16.96 \mathrm{~km}^{2}$, corresponding to $6.01 \%$ from 2016 to 2019 . "Pastureland" also exhibited significant changes, with an increase of $26.74 \%$ during the study period.

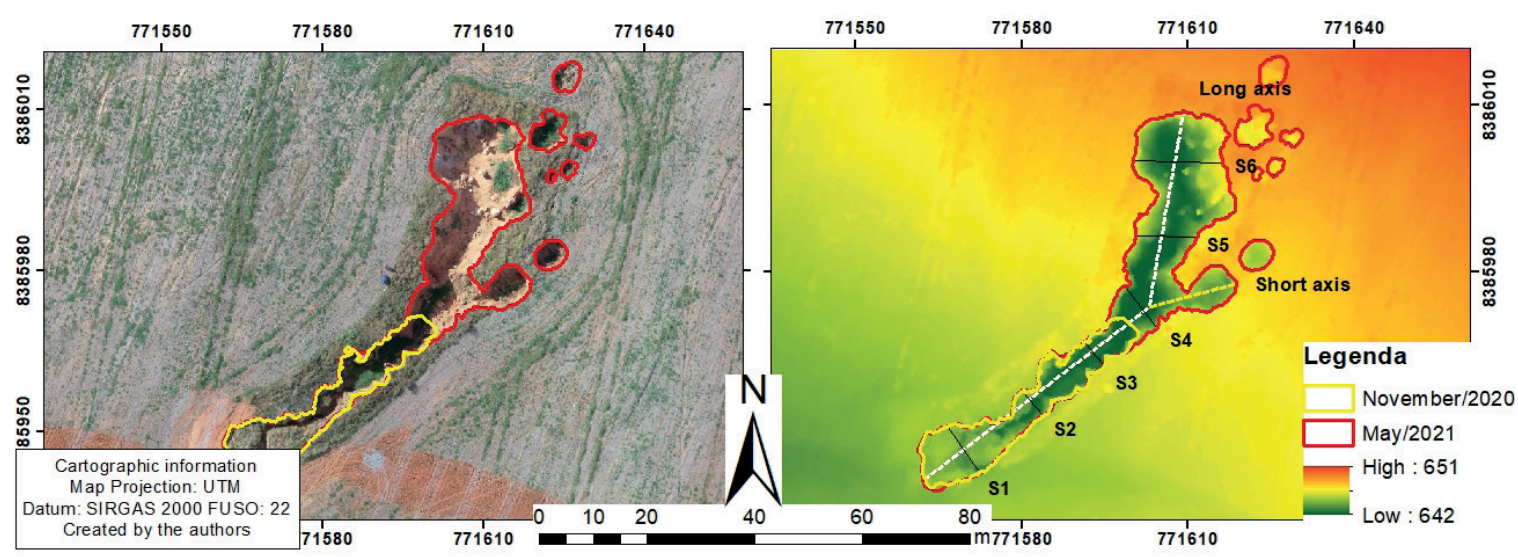

Figure 5. Sinkhole 2: comparison between surveys carried out in November 2020 and May 2021 (Niquelândia, Goiás state, Brazil). 
Table 2. Morphometric characterization of the sinkhole 2 (Niquelândia, Goiás state, Brazil).

\begin{tabular}{|c|c|c|c|c|c|c|c|c|c|c|}
\hline Period & Area $\left(\mathrm{m}^{2}\right)$ & Maximum depth (m) & Long axis & Short axis & $\mathrm{S} 1 *$ & $\mathrm{~S} 2 *$ & $\mathrm{~S} 3 *$ & S4* & $\mathrm{S} 5 *$ & S6* \\
\hline November 2020 & 299.96 & 3.93 & 46.62 & - & 10.07 & 5.85 & 5.56 & - & - & - \\
\hline May 2021 & 961.66 & 6.95 & 87.27 & 16.17 & 10.44 & 5.96 & 5.50 & 9.74 & 11.01 & 16.1 \\
\hline
\end{tabular}

* Cross-sections identifying the variations and increase in the diameters of the sinkhole 2.
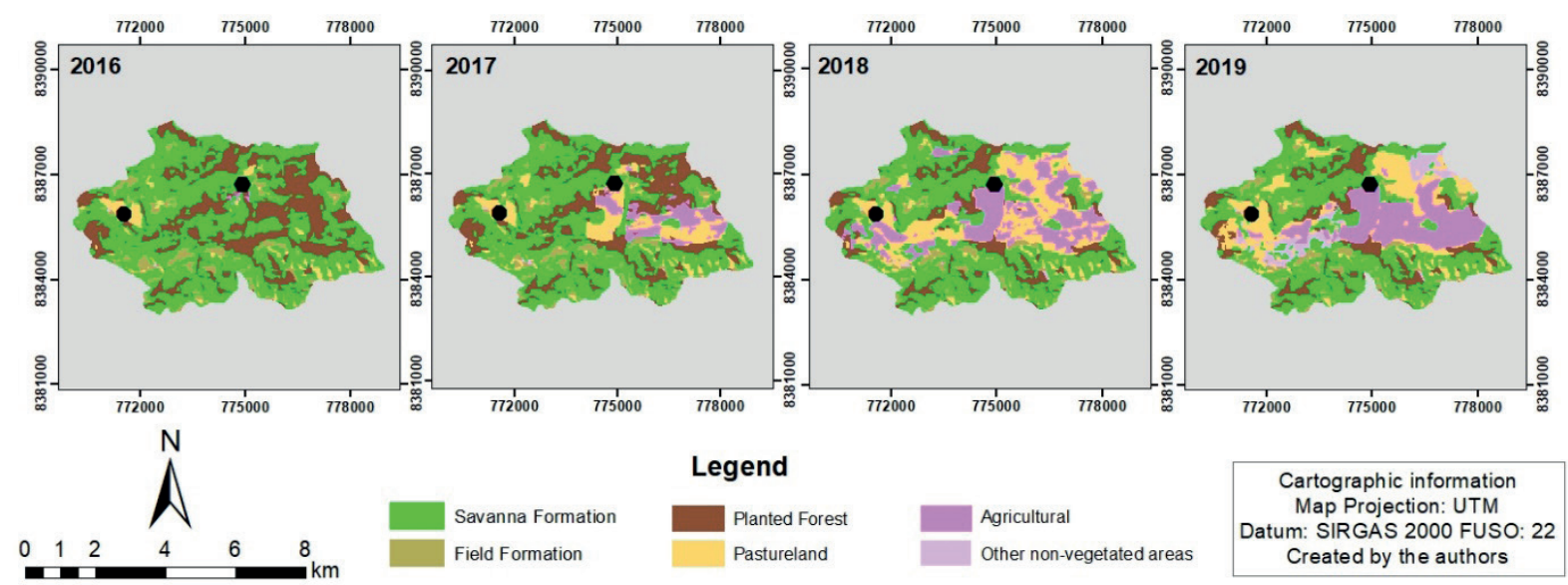

Figure 6. Use and occupation of soil adjacent to the sinkholes (2016-2019) (Niquelândia, Goiás state, Brazil). Source: Mapbiomas (2021).

Medium to high-resolution images were assessed to identify the period of sinkhole emergence. The images used and their respective descriptions are depicted in Table 3.

The depressions were difficult to recognize, because they were too small to clearly distinguish on most of the satellite images available. However, the sinkholes could be seen on the high-resolution CBERS 4 and CBERS 4A satellite images in the panchromatic band, with spatial resolution of 5 and $2 \mathrm{~m}$, respectively.

Based on the images available, it was observed that the region was densely vegetated between 2000 and 2013. There are no data available between 2014 and 2018, but both sinkholes can be observed for 2019 and 2020.

The images obtained by the CBERS 4 satellite, corresponding to the panchromatic band (510-850 nm), with spatial resolution of $5 \mathrm{~m}$, made it possible to identify the period of sinkhole emergence, but it is important to note that their subterranean evolution occurred over a longer period. According to the CBERS 4 satellite images, the surface of the sinkhole 1 collapsed between December 2018 and May 2019, a period corresponding to the growing season and rainfall in

Table 3. Satellite images analyzed for the Felipa hydrographic basin (Niquelândia, Goiás state, Brazil).

\begin{tabular}{llcc}
\hline \multicolumn{1}{c}{ Images } & Spatial resolution & Available period & Visualized sinkholes \\
\hline LANDSAT 8 & $\begin{array}{l}\text { Panchromatic: } 15 \mathrm{~m} \\
\text { Multispectral: } 30 \mathrm{~m}\end{array}$ & 2013 to 2021 & no \\
\hline SENTINEL 2 & Multispectral: $10 \mathrm{~m}$ & 2015 to 2021 & no \\
\hline CBERS 4 & $\begin{array}{l}\text { Panchromatic: } 5 \mathrm{~m} \\
\text { Panchromatic: } 15 \mathrm{~m} \\
\text { Multispectral: } 20 \mathrm{~m}\end{array}$ & 2015 to 2021 & $\begin{array}{l}\text { yes } \\
\text { no } \\
\text { no }\end{array}$ \\
\hline CBERS 4A & $\begin{array}{l}\text { Panchromatic: } 2 \mathrm{~m} \\
\text { Multispectral: } 8 \mathrm{~m}\end{array}$ & $2020 / 2021$ & yes \\
\hline Google Earth & Depends on the image & $2000 / 2011 / 2013 / 2019 / 2020$ & yes \\
\hline
\end{tabular}

Source: Adapted from INPE (2019). 
the region. After determining the period of erosion onset, the sinkhole 1 was observed during a field visit in April 2019.

Although the sinkhole 2 could not be identified in the satellite images until around November 2019, the field visit in April 2019 revealed that the depression already existed. Based on the images available, an exact date could not be established for the emergence of the sinkhole, due to the time elapsed between the satellite passovers and cloud cover during the rainy season.

The changes in soil use identified in the area could contribute to the appearance of these sinkholes. According to Kiernan (1988), deforestation may increase the soil temperature and change its $\mathrm{CO}_{2}$ levels, making unfiltered water more acidified and more aggressive in the karst environment, strengthening and accelerating carbonate rock dissolution, as observed in the changes that occurred in both sinkholes. Urich (2002) reported that mechanized agriculture in karst areas may intensify the impacts of soil erosion, given that the detached materials are transported to conduits and crevices that may lead to caves. Since these depressions have been filled, the dissolution processes responsible for speleothem formation may be interrupted.

Based on the survey and processed data, it was possible to measure the amount of soil lost during the UAV image acquisition period, when the volume was calculated for the sinkholes, as well as the approximate density $\left(1.4 \mathrm{~g} \mathrm{~cm}^{-3}\right)$ of Oxisol in the region (Table 4).

The results show that the volume of the sinkhole 1, in November, was $169.21 \mathrm{~m}^{3}$, corresponding to 236.89 metric tons of soil, which was eroded to the subterranean medium. According to the second survey conducted in May, the sinkhole 2 has been filled, further aggravating the impact on underground conduits, given that the filling material migrates vertically in the depression.
In November, the sinkhole 2 had an area of $299.96 \mathrm{~m}^{2}$ and volume of $721.34 \mathrm{~m}^{3}$, corresponding to a loss of 663.47 metric tons of soil. In order to compare the same area of the first aerial survey, the sinkhole 2 area was divided into two parts, the first representing the area of the initial sinkhole, and the second (new area) the increase in the area from one period to another. Even for a short time period of approximately 6 months, the volume increased by around $34.30 \%$, corresponding to a loss of 346.40 metric tons of soil.

The different depths in this sinkhole between the two analyzed periods, despite being apparently significant, could not be easily assessed due to two factors: i) the large amount of rainfall in November (which underestimated the real depth); ii) the high risk of slope collapse caused by the geotechnical instability of the sinkhole (which could threaten the physical integrity of the researchers).

The new area of the sinkhole 2 was $650.93 \mathrm{~m}^{2}$, for a volume of $2,308.44 \mathrm{~m}^{3}$, corresponding to $3,231.81$ metric tons of lost soils. A total of more than 4,000 metric tons of soil were lost in this sinkhole alone.

These types of analyses are more common for conventional erosional features, but not as much for karst features, even though the impacts caused are quite concerning. Using an empirical model, Febles-González et al. (2011) measured the soil loss in sinkholes caused by water flows in 1986, 1997 and 2009, and calculated an average loss between 12.3 and 13.7 metric tons ha $^{-1}$ year $^{-1}$ in the study period.

Erosional features usually transport the lost material to a more sloping relief, directed primarily to valley floors and water channels (Merritt et al. 2003). However, with karst features, especially sinkholes, the lost materials are not visualized superficially, but rather incorporated into the feature and may trigger several other impacts, such as intensification of the karstification process, due to changes in the

Table 4. Soil loss for the sinkholes 1 and 2 (Niquelândia, Goiás state, Brazil).

\begin{tabular}{|c|c|c|c|c|c|}
\hline Feature & Period & Area $\left(\mathrm{m}^{2}\right)$ & Volume $\left(\mathrm{m}^{3}\right)$ & Mass (t) & Area evolution (\%) \\
\hline \multirow{2}{*}{ Sinkhole 1} & Nov. 2020 & 35.53 & 169.21 & 236.89 & Not applicable \\
\hline & May 2021 & 0.00 & 0.00 & 0.00 & Filled \\
\hline \multirow{2}{*}{ Sinkhole 2} & Nov. 2020 & 299.96 & $>473.91^{(1)}$ & $>663.47^{(1)}$ & Not applicable \\
\hline & May 2021 & 310.73 & 721.34 & $1,009.87$ & 152.21 \\
\hline Sinkhole $2^{(2)}$ (new area) & May 2021 & 650.93 & $2,308.44$ & $3,231.81$ & Not applicable \\
\hline
\end{tabular}


physicochemical properties of unfiltered water in the karst system (Vital \& Travassos 2015).

These features also cause monetary losses to farmers, who will lose the entire soil volume, including the surface horizon, the most fertile portion with the largest amount of humus and where fertilizers are applied (Andreoli et al. 2014). In addition to soil, the agrochemicals used on the planted crops may also be lost. The fast transformation potential of these features represents an additional risk, whereby agricultural machinery may further destabilize the terrain and cause work accidents.

\section{CONCLUSIONS}

1. The karst features, such as sinkholes, identified in the Legado Verdes do Cerrado reserve emerged during the rainy season, between December 2018 and April 2019;

2. Changes in the soil use and cover between 2016 and 2019, which resulted in an increase in agricultural areas and a decline in forest areas, favored the emergence and fast expansion of sinkholes, due to intensified carbonate rock dissolution;

3 . The sinkhole 1 cavity represented a soil loss of 236.89 metric tons in an area of only $35.53 \mathrm{~m}^{2}$, and was subsequently completely filled as a means of mitigating the impact and allowing new grain crops in the area. The sinkhole 2 cavity exhibited a cumulative loss of more than 4,000 metric tons of soil, increasing significantly over a short time period (six months);

4. Satellite images were essential to point out the approximate period of the emergence of sinkholes; but, for reasons of scale, it was not possible to obtain the morphometric characteristics of the sinkholes identified. From the unmanned aerial vehicle, this morphometric analysis and calculation of soil loss was possible, which generated a saving of work time, in addition to a greater security in data collection, in an environment of high geotechnical instability.

\section{ACKNOWLEDGMENTS}

We are grateful to the Graduate Geography Program of the Universidade Federal de Goiás, the management of the Legado Verdes do Cerrado reserve for use of their facilities and logistical support, and the Fundação de Amparo à Pesquisa do Estado de Goiás
(FAPEG), Reservas Votorantim Ltda. and Coordenação de Aperfeiçoamento de Pessoal de Nível Superior (Capes) for funding this research.

\section{REFERENCES}

ADÃO, T.; HRUŠKA, J.; PÁDUA, L.; BESSA, J.; PERES, E.; MORAIS, R.; SOUZA, J. J. Hyperspectral imaging: a review on UAV-based sensors, data processing and applications for agriculture and forestry. Remote Sensing, v. 9, n. 11, p. 1-30, 2017.

ANDREOLI, C. V.; ANDREOLI, F. D. N.; JUSTI JUNIOR, J. Formação e características dos solos para o entendimento de sua importância agrícola e ambiental. Complexidade: redes e conexões do ser sustentável. Curitiba: Senar/PR, 2014.

BARCELOS, A. C. O uso de veículo aéreo não tripulado (VANT) em monitoramentos de campo: aplicabilidades e viabilidades. Uberlândia: Ed. UFU, 2017.

BECK, B. Soil piping and sinkholes failures. In: WHITE, W. B.; CULVER, D. C. (ed.). Encyclopedia of caves. 2. ed. New York: Elsevier, 2012. p. 718-723.

BOONPOOK, W.; TAN, Y.; LIU, H.; ZHAO, B.; HE, L. UAV-based 3D urban environment monitoring. ISPRS Annals of Photogrammetry, Remote Sensing \& Spatial Information Sciences, v. 4, n. 3, p. 37-43, 2018.

CARVAlHO, O. A.; GUIMARÃES, R. O.; MONTGOMERY, D. R.; GILLESPIE, A. R.; GOMES, R. A. T.; MARTINS, E. S.; SILVA, N. C. Karst depression detection using ASTER, ALOS/PRISM and SRTMderived digital elevation models in the Bambuí Group, Brazil. Remote Sensing, v. 6, n. 1, p. 330-351, 2014.

CUNHA, A. A.; ALIXANDRINI JUNIOR, M. J.; OLIVEIRA, F. V. Avaliação de erosão por imagens de aeronave remotamente pilotada a baixa altura de voo. Geografia, v. 29, n. 1, p. 191-210, 2020.

FEBLES-GONZÁLEZ, J. M.; VEGA-CARREÑO, M. B.; BECERRA, A. T. Assessment of soil erosion in karst regions of Havana, Cuba. Land Degradation \& Development, v. 23, n. 5, p. 465-474, 2011.

FERREIRA, C. F.; UAGODA, R. E. S. Um panorama sobre mapeamentos de dolinas no Brasil, feições elementares do carste. Revista Brasileira de Geografia Física, v. 13, n. 1, p. 302-321, 2020.

FORD, D.; WILLIAMS, P. Karst hydrogeology and geomorphology. 2. ed. Chichester: John Wiley \& Sons, 2007.

HIRUMA, S. T.; FERRARI, J. A.; AMARAL, R.; HONÓRIO, R. F. Mapeamento e caracterização de feições cársticas de superfície na faixa Itaiacoca nas regiões de 
Nova Campina e Bom Sucesso de Itararé, SP/PR. Revista do Instituto Geológico, v. 27, n. 1-2, p. 1-12, 2007.

INSTITUTO NACIONAL DE PESQUISAS ESPACIAIS (INPE). CBERS: usos e aplicações. 2019. Available at: http://www.cbers.inpe.br/sobre/usos_aplicacoes.php. Access on: Sep. 24, 2021.

KIERNAN, K. The management of soluble rock landscapes: an Australian perspective. Sydney: The Speleological Research Council, 1988.

LACERDA FILHO, J. V.; REZENDE, A.; SILVA, A. Geologia e recursos minerais do Estado de Goiás e do Distrito Federal. Goiânia: CPRM, 1999.

LEPSCH, I. F.; BELLINAZZI, R.; BERTOLIN, D.; ESPÍNDOLA, C. Manual para levantamento utilitário do meio físico e classificação de terras no sistema de capacidade de uso. São Paulo: Sociedade Brasileira de Ciência do Solo, 1983.

MAPBIOMAS. Coleção 6 da série anual de mapas de uso e cobertura da terra do Brasil. 2021. Available at: https://mapbiomas.org/colecoes-mapbiomas-1?cama_set_ language=pt-BR. Access on: Sep. 24, 2021.

MERRITT, W. S.; LETCHER, A.; JAKEMAN, A. J. A review of erosion and sediment transport models. Environmental Modelling \& Software, v. 18, n. 8-9, p. 761-799, 2003.

NASCIMENTO, D. T. F.; NOVAIS, G. T. Clima do Cerrado: dinâmica atmosférica e características, variabilidades e tipologias climáticas. Eliséé, v. 9, n. 2, e922021, 2020.

PARDO-IGÚZQUIZA, E.; VALSERO, J. J. D.; DOWD, P. A. Automatic detection and delineation of karst terrain depressions and its application in geomorphological mapping and morphometric analysis. Acta Carsologica, v. 42, n. 1, p. 17-24, 2013.

PEREIRA, O. J. R.; MELFI, A. J.; MONTES, C. R. Image fusion of Sentinel-2 and CBERS-4 satellites for mapping soil cover in the wetlands of Pantanal. International Journal of Image and Data Fusion, v. 8, n. 2, p. 148-172, 2017.

PESSI, D. D.; BELIN, R. B.; MIRANDA JÚNIOR, P. L.; SILVA, N. M. Aeronaves remotamente pilotadas e suas aplicações no manejo agrícola e ambiental. Cadernos de Ciência \& Tecnologia, v. 37, n. 2, p. 1-19, 2020.

SANTOS, H. G.; CARVALHO JUNIOR, W.; DART, R. O.; AGLIO, M. L. D.; SOUSA, J. S.; FONTANA,
A.; MARTINS, A. L. S.; OLIVEIRA, A. P. O novo mapa de solos do Brasil: legenda atualizada, escala 1:5.000.000. Rio de Janeiro: Embrapa Solos, 2011.

SILVA, B. B. Aplicações ambientais brasileiras de geoprocessamento e sensoriamento remoto. Campina Grande: Embrapa Algodão, 2014.

SOUZA FILHO, P. W. M.; PARADELLA, W. D.; VALERIANO, D. M.; MIRANDA, F. P. Sensoriamento remoto e recursos naturais da Amazônia. Ciência e Cultura, v. 58, n. 3, p. 37-41, 2006.

TEIXEIRA, P. C.; DONAGEMMA, G. K.; FONTANA, A.; TEIXEIRA, W. G. Manual de métodos de análise de solo. Brasília, DF: Embrapa, 2017.

TELES, E. F. B.; MORAIS, F. Os grandes empreendimentos em áreas cársticas na Amazônia legal brasileira: o caso do estado do Tocantins. Acta Geográfica, v. 13, n. 33, p. 2041, 2019.

UNITED STATES DEPARTMENT OF AGRICULTURE (USDA). Natural Resources Conservation Service. Keys to soil taxonomy. 12. ed. New York: USDA, 2014.

URICH, P. B. Land use in karst terrain: review of impacts of primary activities on temperate karst ecosystems. Wellington: New Zealand Department of Conservation, 2002.

VESTENA, L. R.; KOBIYAMA, M.; SANTOS, L. J. C. Considerações sobre gestão ambiental em áreas cársticas. RA'EGA: O Espaço Geográfico em Análise, v. 6, n. 1, p. 81-93, 2002.

VITAL, S. R. O.; TRAVASSOS, L. E. P. Impactos decorrentes do uso do solo em dolinas da bacia sedimentar da Paraíba, zona oeste do município de João Pessoa (PB), Brasil. Caderno de Geografia, v. 25, n. 44, p. 118-133, 2015.

WILLIAMS, P. W. Environmental change and human impact on karst terrains: an introduction. Catena, v. 25, n. 1, p. 1-19, 1993.

ZANETTI, J. Influência do número e distribuição de pontos de controle em ortofotos geradas a partir de um levantamento por VANT. Viçosa: Ed. UFV, 2017.

ZWAHLEN, F. Vulnerability and risk mapping for the protection of carbonate (karst) aquifers: final report (COST action 620). Luxembourg: Office for Official Publications of the European Communities, 2004. 